\title{
'If I had begun to dance': Women's Performance in Kemps Nine Daies Wonder
}

In The Travels of the Three English Brothers (1607) by John Day, William Rowley, and George Wilkins, the famous English clown Will Kemp meets an Italian actress. Kemp finds himself in Venice preparing to collaborate with an Italian harlequin on a play for Sir Anthony Shirley, one of the eponymous English brothers. When the harlequin tells Kemp that his company consists of 'None but my wife and myself, sir', Kemp's interest is lasciviously piqued. ${ }^{1}$ In his brief exchange with the harlequin, Kemp focuses almost exclusively on the actress/wife, implying through heavy innuendo the inevitable sexual availability of women players. When Harlequin attempts to cast Kemp as a servant who must 'keep my wife', Kemp responds, 'who so fit to make a man a cuckold as he that keeps his wife?' (121-3). Leaning over to kiss the wife, Kemp reassures Harlequin that 'We are fellows, and amongst friends and fellows, you know, all things are common' (114-16). In the guise of good fellowship, Kemp reproduces the misogynist and xenophobic attitude about foreign actresses found in texts like Pierce Pennilesse, where Thomas Nash praises English actors at the expense of 'players beyond the sea' who 'have Whores and common Curtizens to playe womens partes. ${ }^{2}$ Within the fiction of the play, Kemp may be collaborating with the Italian duo, but he views his collaborators with a contempt grounded in his negative stereotype of women performers. ${ }^{3}$

In marked contrast to the character Kemp in The Travels of the Three English Brothers, the historical William Kemp is much more sympathetic to women's performance in the pages of his own slender pamphlet, Kemps Nine Daies Wonder (1600). An account of Kemp's morris dance from London to Norwich shortly after he left his position as the principal clown in the Chamberlain's Men, Kemps Nine Daies Wonder features several women Kemp met along the way, including two who joined his dance, one at Chelmsford and one at Sudbury. ${ }^{4}$ Women are involved in Kemps Nine Daies Wonder at every 
turn, watching Kemp dance, welcoming him into their communities, and performing with him in front of large audiences. ${ }^{5}$ As scholars have insisted, Kemps Nine Daies Wonder is not an objective historical account of Kemp's dance but rather a carefully constructed self-presentation; women's prominent role in the volume therefore suggests that Kemp saw their participation as integral to the success of his venture. ${ }^{6}$ Unlike The Travels of the Three English Brothers, Kemps Nine Daies Wonder establishes that positive representations of women's performance could enhance rather than threaten the status of the professional male performer.

By showcasing the ease with which women join Kemp's dance and the expertise they bring to it, Kemps Nine Daies Wonder suggests a great deal about the broad cultural phenomenon of women's performance. Most clearly, it establishes the customary and unexceptional nature of women's performance. ${ }^{7}$ Recent scholarship has shown that women's active participation in the world of performance was the rule, not the exception, all across England. James Stokes, for example, identifies an unbroken tradition of female performance stretching back hundreds of years in counties as varied as Somerset, Devon, and Lincolnshire. ${ }^{8}$ Gweno Williams, Alison Findlay, and Stephanie Hodgson-Wright show that women in York, Gloucestershire, and Lancashire were deeply involved in performance. They say that for the York Corpus Christi cycle alone, 'documentation reveals that women engaged in a wide range of key activities for this major annual collective theatrical enterprise, including finance, planning, production, staging, and audience management'. 'Sara Mueller notes that women were prominent on the provincial touring circuits, too: 'the records indicate that touring women performers were acknowledged as professional entertainers, licensed by the state to perform, and paid for their performances in cities, towns, and households across the country' ${ }^{10}$ Other scholars have conclusively established widespread patronage activities as an essential aspect of women's involvement in English performance. ${ }^{11}$ This picture of a culture that accommodates women's performance clearly changes the long-standing scholarly understanding of the 'all-male' nature of performance in early modern England. ${ }^{12}$ Women's performance activities included 'singing songs and ballads, dancing jigs, cross-dressing, miming, jesting, and masking'; the venues for women's performance encompassed the 'playing areas of the street, alehouse, market square, parish green, manorhouse and court'. ${ }^{13}$ As Stokes writes in this issue, 'archival research continues to provide a wealth of evidences that local women participated (as actors, 
producers, and patrons) in every performative aspect of local culture in medieval and early modern England'. ${ }^{14}$

Women's roles in Kemps Nine Daies Wonder bear out the recent scholarship on women's performance: Kemp's morris dance was an extraordinary one-off event that gave local women the opportunity to demonstrate their unremarkable familiarity with the rituals and customs of performance and their ability to participate in a physically demanding form of performance when the opportunity arose. Kemp's treatment of the women who danced with him additionally suggests that male players from the professional London stage were capable of recognizing women as skilled performers and entering into mutually supportive relationships with them. If the Kemp of The Three English Brothers seeks to discredit women performers, the Kemp of Kemps Nine Daies Wonder welcomes what they have to offer. Giving women space on his ludic field, Kemp enables them to assert their identities in complex negotiations with their communities. In return, their labours help him enhance his image as a funnier, more skilled, and more generous performer than he might otherwise appear. If Kemps Nine Daies Wonder is any guide, then, at least in some circumstances, cooperation rather than competition was the order of the day between women and men in English performance.

Whether women enter Kemp's narrative as patrons, audience members, or fellow performers, they are essential to his dancing venture and profoundly shape its character. Most notable among the women Kemp encounters are the young girl at Chelmsford and the country lass at Sudbury who actually dance with him. But other women, too, play significant roles throughout Kemp's project. For example, Kemp opens the pamphlet with a dedicatory epistle to 'his most bountifull Mistris, the Mistris Anne Fitton, Mayde of Honour to the most sacred Mayde Royall Queene Elizabeth' (3), thereby framing the entire project in terms of a privileged female reader and, more broadly, the principle of female patronage and protection. ${ }^{15}$ As the narrative progresses, Kemp several times mentions the women in his audiences, noting the 'many Gentlemen and Gentlewomen' (10) gathered to see him at Chelmsford and the 'divers knights and Gentlemen, together with their wives and Children' (22) who prepared to receive him at Norwich. Welcomed into Norwich, he attests that the mayor's 'bounty, and kind vsage, together with the general welcomes of his worshipful brethren, and many other knights, Ladies, Gentlemen \& Gentlewomen, so much exceeded my expectation, as I adiudg'd my selfe most bound to them all' (26). At Bury, a wealthy widow, 'the widdow Eueret' (16), hosts a large community gathering 
to honour Kemp. 'At her house', Kemp reports, 'were met aboue thirty Gentlemen. Such, and so plentifull variety of good fare, I haue very sildome seene in any Commoners house' (16). Kemp repays the widow Everet's hospitality by commending her character: 'Her behauiour being very modest and freendly, argued her bringing vp not to be rude. She was a woman of good presence: and if a foole may iudge, of no smal discretion' (16). Throughout his journey, then, Kemp profits from women's attention and generosity, and he never loses sight of their role. Near the end of his pamphlet, Kemp evokes the grandest female patron of all, directly assuring Anne Fitton that 'all my mirths (meane though they be) haue bin $\&$ euer shal be imploi'd to the delight of my royal Mistris' (27).

While Kemps Nine Daies Wonder proves that the London star Will Kemp can adapt to, even embrace, cultures of female performance familiar across England, he comes to the world of women's performance by way of his own self-interest. He undertakes the dance from London to Norwich as a selfpromotional stunt to fatten his purse and enhance his career. David Wiles says that 'Kemp conceived his dance to Norwich as a commercial venture, and he invited spectators to gamble on his failure. ${ }^{16}$ Max Thomas sees Kemps Nine Daies Wonder primarily as Kemp's effort to transform the festive morris dance of traditional culture into a profit-oriented event that would increase Kemp's long-term marketability. In Thomas's analysis, Kemp depicts himself as a free agent on the open market, admitting that 'I put out some money to haue threefold gaine at my returne' (27), and complaining that most of those who wagered on him failed to pay up when he succeeded. Thomas holds that Kemp 'rejects the medieval tradition of revelry ... dancing through, rather than with, the community', and certainly Kemp often seems less concerned to dance with the people he meets along his way than to move past them and resume his linear progress to Norwich. ${ }^{17}$ He several times recounts that he refused to drink with his well-wishers: 'to their ful cups, kinde thanks was my returne, with Gentlemanlike protestations: as, truly sir, I dare not: it stands not with the congruity of my health' (6). Ronda Arab sees Kemp's restraint as part of his effort to establish his masculine identity. For Arab, 'Kempe's narrative functions as a performative speech act that mediates discourses of masculinity, work, and the professional player by writing the player as a skilled working man whose dancing is his labor'. ${ }^{18}$ One of the goals of Kemps Nine Daies Wonder is thus to confute 'the many accusations of idleness and effeminacy leveled at workers of the theater in early modern England'. ${ }^{19}$ 
While critics rightly show Kemp's commitment to promoting a desired self-image, the emphasis on his own self-fashioning tends to obscure the contributions of others who populate his pamphlet, including the strategies and the goals that these figures bring to bear on performance. An exploration of women's significant role in Kemps Nine Daies Wonder, for example, reveals that women's performances often have less to do with Kemp's agenda than with the women's own. Exploring how the women who dance with Kemp pursue their own goals is potentially risky because the task might seem to assume modern readers can access the deep motivations of textualized figures. Any such assumption would be untenable: since Kemp has his own agenda in Kemps Nine Daies Wonder, his own complex motives come into play when he represents women's acts of self-representation. The inescapable conditions of writing thus compromise any definitive claims about who the women are and what they want. Making the analysis of women's performance even more difficult is the methodological challenge that attends all scholarship on scantily documented historical sources. What Sara Mueller says about recovering the work of itinerant women performers also holds true of the women dancing in Kemps Nine Daies Wonder: 'because the records themselves are slippery, biased, and grounded in the time and place of a single instance, I question strictly positivist approaches to reading the archives'. Instead, Mueller proposes 'a method of reading the records which pairs a positivist approach with one that acknowledges the ambiguous, sitespecific, and temporal nature of each individual dramatic record'; such a method 'both recovers the labour of women theatre professionals and has the potential to reveal the politics of individual performances'. ${ }^{20}$ Although the present essay deals with amateur performers rather than professionals, it adopts Mueller's method, linking a site-specific analysis of women's dancing to broad cultural claims about the implications of their performances. By drawing on the insights of recent scholarship on women and performance, the essay offers plausible claims about the women who dance with Kemp without implying privileged access to their motivations, or to Kemp's. In this way the essay seeks to expand our sense of how local and occasional performance could be a powerful means for women to construct and communicate desired self-images. It also seeks to demonstrate that, for women and men alike, self-assertion through performance benefitted from collaboration.

Carefully then, but with confidence, this essay argues that the two women who dance with Kemp exploit his presence in their communities for their own ends. For all that Kemp tries rhetorically to enfold them into his project, 
their dancing raises questions that do not primarily refer to him: questions about their opportunities to perform, their motivations for dancing, and their use of the dance to negotiate their own identities within their communities. In short, the women who dance with Kemp operate within the customary world of female performance. The fact that Kemp gives them so much room to do so suggests that he understands their contributions not as antithetical but as complementary to his own goals. Together Kemp and the women dazzle spectators and readers through their physical and verbal prowess, together they outperform most of the men they encounter, and together they prod one another to realize their full potential as performers. Even when we might expect to find Kemp and the women locked into a competitive dynamic based on divergent goals, they are linked by shared interests and the need to collaborate.

The benefits of collaboration merit special consideration in Kemps Nine Daies Wonder because the stakes of performance are high both for Kemp and for the women who dance with him. Kemp repeatedly conveys that his dancing and the dancing of anyone who joins him is subject to ridicule should it fail. Indeed, Kemp reports that on the first day of his dance, crowds accompanied him out of London, 'perhappes to make themselves merry, if I should chance (as many thought) to give over my Morrice within a mile of Mile-end' (6). He mentions, too, that at Burntwood on the second day of his dance, authorities questioned him about two cutpurses who had followed him from London. When apprehended, the suspects claimed to have 'laid wagers and betted about my iourney' (9). Kemp denies their acquaintance, but, as Arab points out, 'Kempe is almost accused of being an accomplice; the potential for the morris-dancing journeyer to be taken for a vagrant thief is clear here. ${ }^{21}$ Kemp explicitly associates the cutpurses with the early modern entertainment industry when he mentions the practice in theatres of tying pickpockets to posts on stage 'for all people to wonder at, when at a play they are taken pilfering' (9). Although Kemp wishes 'that the whole world were cleer of such companions' (9), performance itself creates the conditions in which thievery can thrive. Performance, then, is not simply about pleasure and inclusiveness - it always also entails the risk of failure, loss, and the possibility of shaming. As early as the epistle to Anne Fitton, Kemp raises the ever-present dangers of performance, in this case in his claim that certain balladeers have misrepresented his morris in print: 'I shall appeare to the world without a face', he writes to Mistress Fitton, 'if your fayre hand wipe not away their foule coulors' (3). The image of Kemp losing and regaining 
face makes it abundantly clear that his identity is at stake in his performance: a desired identity if the performance succeeds and a humiliating one if it fails. The same stakes hold true for the women who join Kemp's performance along the way.

One notable moment in Kemps Nine Daies Wonder involves the humiliation of a young girl who inadvertently became a part of Kemp's performance. She joins the crowd watching him dance his way into Norwich and gets too close to him. As Kemp puts it:

As I was fetching a leape, it fell out that I set my foote on her skirts: the point eyther breaking or stretching, off fell her petticoat from her waste, but as chance was, thogh hir smock were course, it was cleanely: yet the poore wench was so ashamed, the rather for that she could hardly recover her coate againe from unrulie boies, that looking before like one that has the greene sicknesse, now she had her cheeks all coloured with scarlet. I was sorry for her, but on I went towards the Maiors. (25)

This incident highlights the sexual dangers of performance, which are capable at any moment of overwhelming any individual's efforts to contain them. The young woman apparently seeks only to be a member of Kemp's audience, but Kemp represents her sexually, linking her to green sickness and framing her as a virgin out of her depth in the implicitly erotic milieu of the dance and the crowd. When part of her clothing comes off, she is forced into a spin-off performance, a sexualized spectacle in which the rowdy boys entertain themselves, and presumably others, by withholding her petticoat and watching her complexion change colour. In Norwich, as elsewhere along Kemp's way, the crowd is full of women, but the example of the young maid shows that even the seemingly safe role of audience member can be fraught with social danger - membership can turn into exclusion in an instant, with potentially threatening sexual consequences for a young maid surrounded by aggressive boys.

The experience of the young woman in Norwich makes it on first glance all the more remarkable that elsewhere on Kemp's journey two other young women not only join crowds to watch but step out of crowds to dance with him, to take up their own place on the field of performance and become objects of the scrutinizing, judging gaze of their communities. But in light of the widespread culture of women's performance, the young women's eagerness to dance with Kemp may not be so strange after all; it may rather attest 
to the normalcy of women's performance, confirming the phenomenon that Stokes has called 'universal cultural suffrage', despite the danger inherent in cultural participation. ${ }^{22}$ If there is a risk to performance, these women are as willing to take it as Kemp is himself. They have a sophisticated understanding of what performance entails: they know its risks and rewards and they know what it takes to showcase themselves to advantage. Unlike the girl who lost her petticoat outside Norwich, for example, the women who dance with Kemp seem to understand the erotic potential of performance, accepting it as integral to their self-display both in terms of their own self-assertion and the audience's response. Their dynamics with Kemp suggest that, for the women (and for Kemp, too), the chance to assert themselves erotically is part of what makes performance thrilling and empowering. Dancing with a star performer from the London stage and collaborating with him as part of his famous act may provide them not just with access to the cultural life of their communities but to ways of imagining themselves as part of a glamorous wider world of erotic energy. At the very least, flirtation and sexual innuendo shape the women's interactions with Kemp and contribute to the collaboration that characterizes performance in Kemps Nine Daies Wonder.

The first woman to dance with Kemp is 'a Mayde not passing fourteen yeares of age' (11), who meets Kemp at Chelmsford. In service, 'she made request to her Master and Dame, that she might dance the Morrice with me in a great large roome' (11). After she receives permission to dance, she makes a further request: Kemp is fitting her out with bells, but she wants more: 'she would have the old fashion with napking on her armes' (11). Kemp obliges, dressing her in the morris dancer's complete costume. Together they dance, and Kemp commends her performance: 'a whole houre she held out: but then being ready to lye downe I left her off: but this much in her praise, I would haue challenged the strongest man in Chelmsford, and amongst many I thinke few would haue done so much' (11).

The young woman from Chelmsford presents a good example of the goals and strategies that could attend female performance. Thomas argues that her dance with Kemp presents 'the challenge of the past' and 'reveals that Kemp's conflict is with the morris dance tradition itself'. ${ }^{23}$ Where Kemp would dance in a straight line from London to Norwich, the girl interrupts his progress - she 'would enclose that linear, contemporary dance in a bounded, antiquarian space. ${ }^{24}$ Thomas's persuasive argument nonetheless underestimates the way that the young woman represents not merely the past but also herself in the present. She may tap into a conservative version of the 
morris tradition ('the olde fashion') but in doing so, she aligns herself with the culture of her community. Revealing herself as a keen reader of social and cultural forms, the young woman uses her knowledge to negotiate a place for herself in the culture of her community. She effectively dances herself into visibility, laying claim to a cultural role that she knows is sanctioned by the legitimacy of custom. When she asks permission to dance, she secures the approbation of her superiors and guarantees the legitimacy of her performance. She also requests the morris dancer's full costume of bells and napkins, transforming herself through the performer's garb to ensure that she will stand out as a dancer alongside Kemp and not be taken for just another spectator. In her desire to perform in a large room, she seeks a bounded space in which people can focus on her and Kemp, creating a context in which the glamour of the London visitor will, at least in part, surely rub off on her. By choosing the room herself, the maid exerts an even greater measure of control, perhaps establishing the space as her 'home court' advantage over the outsider, and certainly asserting her own cultural agency. ${ }^{25}$ In all these ways, the young girl proves herself adept at manipulating the performance situation. She brings herself to Kemp's attention, joins his dance, and performs her way into the consciousness of her community.

In writing about the Chelmsford maid, Kemp strives to retain a position of prominence even as he praises her worth. Thomas has noted that 'Kemp's language makes clear the extent to which he sees their dance as a battle'. ${ }^{26}$ This battle, however, need not end with one of the dancers victorious and the other vanquished. It exemplifies, rather, collaborative sparring in which each player uses the other as a foil to show off his or her own virtuosity and enhance the overall pleasure of the performance. The Chelmsford maid challenges Kemp by literally stopping his show: seizing the agenda, she shifts the dance to an alternative space and provides an entertainment that had not been planned in advance. As a good partner who also needs to please the townspeople, Kemp has little choice but to oblige her. ${ }^{27}$ Kemp may well have joined the locals in extravagantly praising the girl's dancing skills, with the Londoner's admiration becoming part of the show. Kemp also implies a sexual chemistry between himself and the girl when he refers to her readiness to lie down after holding out with him a whole hour. Whatever its precise nature, Kemp's interaction with the girl allows him to promote himself at the expense of the men of Chelmsford, whom he surmises would have had difficulty matching the girl's endurance or, implicitly, his own. By praising the girl at the expense of the men ('I thinke few would 
haue done so much'), Kemp suggests that he alone is her proper partner and that he is therefore superior, physically, sexually, and temperamentally, to the men of her town. ${ }^{28}$

Yet Kemp's rhetorical balancing act is precarious and momentarily heightens the stakes of performance. Kemp says that the girl danced with him for an hour, 'but then being ready to lye downe I left her off'. He stops dancing because she is exhausted, but just for an instant his syntax leaves open the possibility that his own exhaustion ends the dance, that she outlasted him. The context quickly makes it clear that the girl, not Kemp, tires first, but the potential for confusion is real because by this point in his narrative, Kemp has already mentioned his own fatigue several times, most recently when describing his arrival at Chelmsford. Having reached his inn, he greeted the local people not with a dance but with a few words from his window: 'to deale plainely I was so weary, that I could dance no more' (10). By his own admission, Kemp is subject to the same kind of fatigue that the girl experiences; indeed, when he stops the dance to accommodate her exhaustion, Kemp may be doing himself a favour as well. He may have been happy to use her as an excuse to rest his own weary body after an hour of unplanned dancing. In the end, the outcome of the girl's physical competition with Kemp may not be of paramount importance (not to her, anyway). Likely more is at stake for her than outlasting the Londoner - she seems to care most about gaining access to the world of performance itself, putting on the costume, taking the dance floor, and legitimately claiming her part in the cultural life of her community. For Kemp, too, the encounter exceeds the promise of victory in a zero-sum game. He plays off the girl to display his own generosity of spirit and ability to adapt to changing circumstances. In all these ways, Kemp's dance with the Chelmsford maid constitutes an instance of cooperative performance, the delight of which lies in watching two skilled players use each other to create a whole that is greater than the sum of its parts.

The second woman to dance with Kemp also engages in collaboration although she presents a more competitive persona than the Chelmsford maid, explicitly comparing her skills to men's and openly daring Kemp to meet her on her terms. Thomas calls her 'the single most serious threat to [Kemp's] dancing venture'. ${ }^{29}$ Yet once again, the woman who dances with Kemp may have goals of her own that, far from threatening Kemp's venture, depend on her ability to interact productively with him. Like the young woman at Chelmsford, the woman who dances from Sudbury to Melford appears to be seeking a measure of cultural agency; more important to her than whether 
she outperforms Kemp would likely be establishing her right to dance, displaying her dancing expertise, and presenting herself in a favourable light to the gathered crowds.

This young woman appears in Kemp's narrative when a butcher from Sudbury who had offered to accompany Kemp finds himself unable to dance more than half a mile. ${ }^{30}$ In place of the inept butcher, who protests 'that if he might get 100. Pound, he would not hold out with me', the woman promotes herself with confidence:

As he and I were parting, a lusty Country lasse being among the people, cal'd him faint hearted lout: saying, if I had begun to daunce, I would have held out one myle though it had cost my life. At which words, many laughed. Nay saith she, if the Dauncer will lend me a leash of his belles, Ile venter to treade one mile with him my selfe. I lookt upon her, saw mirth in her eies, heard boldness in her words, and beheld her ready to tucke up her russet petticoate, I fitted her with bels: which she merrily taking, garnisht her thicke short legs, and with a smooth brow bad the Tabrer begin. (14)

In this passage, the 'Country lasse' defines herself as a consummate performer with a deep sense of the rituals of performance and a rich linguistic flair. Her sense of timing is exquisite: as soon as the butcher confesses his fatigue, she pounces. Rhetorically she picks up on the butcher's 'if' statement by wittily reversing it: where he says 'if' as a way of explaining his failure, she repeats it as a way of promising her success. ${ }^{31}$ Jesting at the butcher's expense, the woman gains the crowd's attention and interest: they laugh at her mockery of the butcher, but perhaps they also laugh at her promise to dance a mile with Kemp, believing her incapable of carrying it out. The young woman then turns to Kemp, enlisting his help to make her boast good. Kemp recognizes a fellow performer when he sees one: mirthful, bold, and ready to tuck up her skirt, she knows what it takes to command the attention of spectators. Kemp wastes no time welcoming her into his dance.

The details of the lass's performance suggest her expertise, her ambitions, and her willingness to collaborate with Kemp. Like the girl at Chelmsford, she recognizes and abides by certain performance conventions such as the initial request to be allowed to join the dance. But unlike her counterpart at Chelmsford, this woman makes her request in a public forum in a way that makes it practically impossible for Kemp to refuse her. She is the one, furthermore, who seems to take charge of the dance as it unfolds, bidding 
the taborer begin. But prominent as this woman is, hers is not a solo act. It depends on Kemp's working with her; indeed, the description of their dance makes clear the degree to which it is a pas de deux from start to finish. When the drum strikes, Kemp reports that 'forward marcht I with my merry Maydemarian' (14), indicating that together the two of them evoke the recognizable duo from popular culture and that they are alike subject to the strictures of the morris. ${ }^{32}$ When the dance ends, Kemp gives her drink and pays her 'an English crowne to buy more drinke, for good wench she was in a pittious heate' (14). Kemp's role as the dispenser of reward confers upon himself a kind of preeminence but it also acknowledges that the lass deserves a reward: she has enhanced the value of his dance and he compensates her for it. The moment also establishes a kind of parity between the two dancers because Kemp himself has earlier received money for dancing, the only other figure in the text to have done so. ${ }^{33}$ As well, the performance of courtesies that accompanies the exchange of money suggests a high level of interconnectivity between Kemp and the lass as performers. Kemp says, 'my kindness she requited with dropping some dozen of short courtsies, and bidding God blesse the Dauncer, I bad her adieu' (14). Here the two engage in a delicate dance of ritual formalities, maintaining their performance until the very moment when 'wee parted friendly' (14).

If Kemp were primarily interested in dominating and discrediting other performers, as the critical literature on Kemps Nine Daies Wonder holds, then the country lass would represent the most serious challenge to Kemp's status as the hero of his own narrative, showing the degree to which a skilled amateur woman performer could hold her own against a professional male counterpart. ${ }^{34}$ Kemp never openly acknowledges the lass as a threat, but nonetheless at moments he seems to be trying to contain her rhetorically. Even by calling her a 'Country lasse', Kemp may be activating the familiar bawdy pun to reduce his partner to the status of erotic object and her dance to that of sexual display. If the lass's bold, mirthful glance and her choice to tuck up her petticoat before dancing signal her own assertion of erotic agency, Kemp answers by describing her body in comic fashion, with special attention to its breaches of feminine decorum: she 'shooke her fat sides' (14), he says; then, in a commemorative verse ostensibly supplied by a friend of Kemp's, the lass is described as having a body not quite up to the task she has undertaken, a body that labours and sweats and produces laughter rather than erotic appreciation: 
Her stump legs with bels were garnisht,

Her browne browes with sweating varnish $[\mathrm{t}]$;

Her browne hips when she was lag,

To win her ground, went swig a swag,

Which to see all that came after,

Were replete with mirthful laughter.

A clear sexual subtext attaches to this description of the kinetic body, yet it does not necessarily diminish readers' respect for the dancer's accomplishment. The lass is a prominent figure in Kemp's book; the very fact that Kemp includes 'an odde Rime' (15) about her testifies to her impact on his journey - she provides one of the few occasions in Kemps Nine Daies Wonder when someone other than Kemp is the centre of attention. Kemp spotlights the lass at this moment in the text despite the likelihood that she will thereby steal some of his own thunder. The prominence Kemp accords her suggests that he may be less interested in subordinating her performance to his own than in acknowledging - and exploiting - her as a worthy partner who enriches both his dance and his narrative. For instance, when he calls her 'my merry Maydemarian', he emphasizes that they are working together and not in opposition.

While the description of the lass's body further emphasizes 'Bakhtinian corporeality', as Arab notes, physicality does not necessarily entail denigration in the performance world. In fact, Arab identifies a strategy of recuperation in Kemp in relation to mainstream scorn for the performer's physical body: 'his treatise celebrates bodies that run counter to dominant constructions of power and worth, which emphasized the qualities of spirit and reason over corporeality. ${ }^{35}$ With respect to the boisterous morris dance, the performer's expert display of his or her corporeality, including the display of kinetic sexuality, is at least as important as any display of spirit and reason. Throughout Kemps Nine Daies Wonder, Kemp points to his own body to emphasize a physical self-control that he codes as masculine. In applying a similar language of corporeality to the Sudbury lass, he implicitly acknowledges her physical capacity as a performer and a peer. Although Kemp's carnivalesque framing of her body-'stump legs', 'browne hips', 'swig a swag' — implies a comic outlook, his terms also suggest the degree of physical concentration and skill that make her such a successful performer. Even as he makes the lass a source of genial fun, Kemp also enshrines her as a player whose physical strengths mirror his own. 
Indeed, Kemp's repeated insistence on the woman's physical skills and merry nature recalls the attributes of another great comic performer, namely Kemp himself. The lass has 'mirth in her eies' (14); she dons Kemp's bells 'merrily' (14); and she is 'Blith of blee in heart as merry' (15), all descriptions that could as easily apply to Kemp; throughout Kemps Nine Daies Wonder, Kemp in fact describes himself in precisely these terms, insisting on his 'mad Iigges and merry iestes' (4), his 'merry Morrice daunce' (22), and his 'hart merry' (4). ${ }^{36}$ The spirit of mirth that characterizes them both also informs their basic shared understanding of the morris dance: respecting the skill it demands, both of them also approach it as a permeable form, open to improvisation and interaction with audience members. ${ }^{37}$ Far from repudiating the woman performer as the character Kemp does in The Travels of the Three English Brothers, Kemp in Kemps Nine Daies Wonder uses terms and tropes that clearly turn his female partner into a version of Kemp himself as he would wish to be. She exits the text 'Kindly paide and well commended' (15), just as Kemp himself hopes to do.

Kemps Nine Daies Wonder purports to be an historical account of a unique performance, but we cannot accept the pamphlet as documentary history. As Thomas reminds us, the book is a carefully crafted narrative in which 'Kemp's success would depend ... not solely on his immediate skill as a dancer but also on the lasting effects of his self-presentation'. ${ }^{38}$ What Kemps Nine Daies Wonder can do, however, is offer a glimpse into a world where women were deeply involved in performance; it can hint at the desires women expressed through performance; and it can help us consider the elusive relationship between women's performance and the textual productions of their male counterparts, who, like Kemp, worked in a professional theatre industry that sought to marginalize what women had to offer. On all these counts, Kemp's pamphlet recognizes the legitimacy and the sheer unexceptional nature of women's performance. The pamphlet is important both for the degree to which Kemp allows the women who dance with him to shine in their own right and also for the extent to which it suggests a model of performance in which male and female players could work together successfully rather than locking themselves into hostile competition. 


\section{Notes}

I am grateful to the two anonymous readers of this paper and especially to Helen Ostovich and Amy Tigner for their generous readings and inspired suggestions.

1 John Day, William Rowley, and George Wilkins, The Travels of the Three English Brothers, Anthony Parr (ed.), Three Renaissance Travel Plays (Manchester, 1995), 55-134, 9.83.

2 Thomas Nash, The Unfortunate Traveller and Other Works (Harmondsworth, 1971), 115. Virginia Scott finds the same attitudes in France in Women on the Stage in Early Modern France (Cambridge, 2010), especially in chapters one and two where she questions the sexist premises of many traditional sources of information about early French actresses.

3 Scholars have seen professional rivalry as a motivating force in English representations of Italian players, including the actress figure. In an overview of Elizabethan attitudes towards the Commedia dell'Arte, for example, Kenneth Richards, 'Elizabethan Perceptions of the Commedia dell'Arte', Guinnar Sorelius and Michael Srigley (eds), Cultural Exchange Between European Nations During the Renaissance (Uppsala, Sweden, 1994) suggests that 'we can explain the Elizabethan dramatists' dismissal or disparagement of the activities and qualities of the Italian players as a deliberate strategy of belittlement' (222). Looking specifically at Shakespeare, Pamela Brown, 'The Counterfeit Innamorata, or, The Diva Vanishes', Shakespeare Yearbook 10 (1999) also sees competitive rivalry at work: 'In certain plays the rival players across the Channel, objects of curiosity, projection, and wonder, are both represented (in Burke's sense of "creative adaptation") and deliberately misunderstood. Shakespeare created simulacra of the diva for audiences that couldn't hope to see her' (408).

4 The morris dance was a popular form, but Clare Sponsler, "Writing the Unwritten: Morris Dance and the Study of Medieval Theatre', Theatre Survey 38.1 (1997), discusses the difficulty modern scholars face in trying to understand precisely what it entailed: 'whenever dance enters into systems of signification, it does so in haphazard, partial, and inevitably distorted ways. Much of what we know about medieval morris dancing, for example, comes obliquely from records of payment for costumes and performers or from prohibitions and complaints. While these records point to a number of occasions on which morris dancing took place, they do not reveal much about what those performances consisted of, why they occurred, who performed, or who watched' (75). Describing the actual dance, Sponsler quotes Philip Stubbes's description in Anatomy of Abuses: 'thei tye about either legge twentie, or fourtie 
belles, with riche hande kercheefes in their hands, and somtymes laied a crosse ouer their shoulders and neckes ... then haue thei their Hobbie horses, Dragons and other Antiques, together with their baudie Pipers, and thundderyng Drommers, to strike vp the Deuilles Daunce withal, then marche these Heathen companie towards the Churche and Church yarde, their Pipers piping, their Drommers thonderyng, their stumppes Dauncyng, their belles iynglyng, their handkerchefes swyngyng about their heads like madmen, their Hobbie horses, and other monsters skirmishyng amongest the throng' (79).

5 Kemp claims that he drew sizeable crowds everywhere he went. On the evening of his second day, he danced to Ingerstone, 'stealing away from those numbers of people that followed mee'; even then, he laments that 'doe I what I could, I had aboue fiftie in the company'. Kemps Nine Daies Wonder (London, 1600; rpt Barnes $\&$ Noble, 1966), 10; subsequent references appear parenthetically. On the next morning, he danced towards Chelmsford, 'not hauing past two hundred, being the least company that I had in the day time' (10).

6 For examples of scholars elucidating the motivated nature of Kemp's rhetoric in Kemps Nine Daies Wonder, see Max W. Thomas, 'Kemp's Nine Daies Wonder: Dancing Carnival into Market', PMLA 107.3 (1992) and Ronda Arab, 'Will Kempe's Work: Performing the Player's Masculinity in Kempes Nine Daies Wonder', Michelle M. Dowd and Natasha Korda (eds), Working Subjects in Early Modern English Drama (Aldershot, 2011), 101-13.

7 James Stokes has established the widespread, customary nature of women's performance across England in 'Women and Mimesis in Medieval and Renaissance Somerset (and Beyond)', Comparative Drama 27.2 (1993) and in 'Women and Performance: Evidences of Universal Cultural Suffrage in Medieval and Early Modern Lincolnshire', Pamela Allen Brown and Peter Parolin (eds), Women Players in England, 1500-1660: Beyond the All-Male Stage (Aldershot, 2005), 25-43.

8 See Stokes, 'Women and Mimesis'.

9 Gweno Williams, Alison Findlay, and Stephanie Hodgson-Wright, 'Payments, Permits, and Punishments: Women Performers and the Politics of Place', Women Players in England, 45-67, 47.

10 Sara Mueller, 'Touring, Women, and the Professional Stage', Early Theatre 11.1 (2008), 53.

11 See, for example, Suzanne Westfall, Patrons and Performance: Early Tudor Household Revels (Oxford, 1990); Leeds Barroll, 'Shakespeare, Noble Patrons, and the Pleasures of "Common" Playing', Paul Whitfield White and Suzanne Westfall (eds), Shakespeare and Theatrical Patronage in Early Modern England (Cambridge, 2002), 90-121; Mary A. Blackstone, 'Theatrical Patronage and the Urban Community 
During the Reign of Mary', Shakespeare and Theatrical Patronage, 176-218; Clare McManus, Women on the Renaissance Stage: Anna of Denmark and Female Masquing in the Stuart Court (1590-1619) (Manchester, 2002); Sophie Tomlinson, Women on Stage in Stuart Drama (Cambridge, 2005); and Natasha Korda, 'Women in the Theater', Richard Dutton (ed.), The Oxford Handbook of Early Modern Theatre (Oxford, 2009), 456-73.

12 For a broad overview of these changes see Pamela Allen Brown and Peter Parolin, 'Introduction', Women Players in England, 1-21. The paradigm of the 'all-male' stage applies most plausibly to the professional London stage. Dympna Callaghan reminds us that "Whatever alleged "exceptions" might have existed in early modern culture to the implicit but nonetheless systematic prohibition against female mimesis, there were no women on Shakespeare's stage'. See Callaghan, Shakespeare Without Women (London and New York, 2000), 7. Yet Natasha Korda points out that 'the historical account of the "all-male stage" is a product of perspective, that is, of the disciplinary parameters scholars have established in defining what are considered to be the proper objects of theater history. If we shift our perspective, alter our established parameters, things may begin to look rather different'. See Korda, 'Women in the Theater', 457. Korda herself begins to shift the parameters in her work on women in the informal economy surrounding the professional stage. See Korda, Labors Lost: Women's Work and the Early Modern English Stage (Philadelphia, 2011).

13 Brown and Parolin, 'Introduction', 4, 1.

14 James Stokes, 'Women and Performance in Medieval and Early Modern Suffolk', Early Theatre 15.1 (2012), 27.

15 Max Thomas, 'Dancing Carnival into Market', 522, points out that 'Kemp's dedication excludes the aristocratic world, for Anne Fitton had no direct links to the court'. Thomas notes that Anne's younger sister Mary was the maid of honour. Nonetheless, for the purposes of his narrative, Kemp evokes the world of aristocratic women's patronage when he names Anne a maid of honour to the queen.

16 David Wiles, Shakespeare's Clown: Actor and Text in the Elizabethan Playhouse (Cambridge, 1987), 25.

17 Thomas, 'Dancing Carnival into Market', 516.

18 Arab, 'Will Kempe's Work', 102.

19 Ibid.

20 Mueller, 'Touring, Women, and the Professional Stage', 53.

21 Arab, 'Will Kempe's Work', 112.

22 Stokes, 'Women and Performance', 28.

23 Thomas, 'Dancing Carnival into Market', 518. 
24 Ibid.

25 Jane Tylus, 'Women at the Windows: Commedia dell'Arte and Theatrical Practice in Early Modern England and Italy', Theatre Journal 49.3 (1997) posits a connection between female spectacle and the space in which that spectacle is produced. Writing about women's frequent appearance at windows and walls in the Commedia dell'Arte, Tylus argues that 'the window or the citadel's wall are places that give the actress both visibility and safety, as she negotiates the boundary between public and private spaces' (324). We might consider the room in which the Chelmsford maid wishes to dance as an extension of the windows and walls that Tylus has explored in commedia. To be sure, the room is not a place from which the maid stands apart from others, but, like the windows and walls, it straddles public and private and presumably includes at least one door, intimating a space beyond the performance where the woman could retreat from the common view. The maid may have chosen the room precisely because it is a space 'in which a woman's honor would be neither challenged nor compromised' (330).

26 Thomas, 'Dancing Carnival into Market', 518.

27 Sensitive to the desires of his crowds, Kemp feels the pressure to please. When he is dancing into Hingham, for example, the young people along the way vie for his attentions, each group wanting him to dance through their particular village or neighborhood, and once again, women play a role: 'For euen as our Shop-keepers will hayle, and pull a man back with Lack ye? What do you lack Gentlemen? ... so was the dyuers voyces of the young men and Maydens, which I should meete at euerie myles ende, thronging by twentie, and sometime fortie, yea hundreths in a companie: One crying the fayrest way was thorow their Village: another, this is the nearest and fayrest way ... that I was so amazed, I knewe not sometime which way I might best take' (21).

28 As Arab points out, 'Kempe's manhood is not defined through the self-sufficient individuality of his own body, but in relation to the bodies that surround him' (Arab, 'Will Kempe's Work', 109).

29 Thomas, 'Dancing Carnival into Market', 519.

30 The failure of so many men who aspire to dance with Kemp is an interesting counterpoint to women's performances in Kemps Nine Daies Wonder. In addition to the failed butcher, two youths dog Kemp's heels on a muddy road on the fourth day of his journey and end up stuck in a puddle: 'I could not chuse but lough to see howe like two frogges they labored' (12-13); additionally, the rotund host of Kemp's inn at Rockland tries to dance with him but after crossing a mere two fields, gives up.

31 The 'if' clause seems almost folkloric in Kemps Nine Daies Wonder, appearing again in the speech of the host of Kemp's inn at Rockland, when he is forced to cede the 
field: 'if thou daunce a Gods name God speede thee: I cannot follow thee a foote farther' (19).

32 For discussions of the history and significance of the morris including its links to Robin Hood games, see Sponsler, 'Writing the Unwritten', and Barbara Lowe, 'Early Records of the Morris in England', Journal of the English Folk Dance and Song Society 8.2 (1957). For discussions of the language of dance, see McManus, Women on the Renaissance Stage, Barbara Ravelhofer, The Early Stuart Masque: Dance, Costume, and Music (Oxford, 2009), and, in this issue, Bella Mirabella, "In the sight of all": Queen Elizabeth and the Dance of Diplomacy'.

33 Kemp reports that on the first day of his morris, 'many good olde people, and diuers others of yonger yeeres, of meere kindnes, gaue me bowd sixepences and grotes' (6).

34 In their persuasive analyses, both Thomas and Arab argue that Kemp seeks to diminish other performers in relation to himself. As Arab states the case, 'while Kempe celebrates the men and women who join him in the dance, he always outdoes them, thus elevating his body as a professional one, even as its professional activity involves including non-professional bodies in its sphere' (Arab, 'Will Kempe's Work', 109). While appreciating this insight, I would like to shift the emphasis to suggest that the interplay between Kemp and the other performers, particularly the women, makes room for, in fact depends upon, a degree of mutuality and respect.

35 Arab, 'Will Kempe's Work', 109.

36 Ibid, 4, 22, 4.

37 For good discussions of Kemp's improvisational approach to the profession of clowning, see Wiles, Shakespeare's Clown, and also Elizabeth Ford, 'Will Kemp, Shakespeare, and the Composition of Romeo and Juliet', Early Theatre 13.2 (2010). Ford considers the degree to which revisions to the Romeo and Juliet text responded to a complex dynamic between the author and the skilled clown capable of brilliant departures from the written script.

38 Thomas, 'Dancing Carnival into Market', 511. 